\title{
SEASONAL EVALUATION FOR HUSSEINIYA STREAM (IRAQ) ACCORDING TO THE CANADIAN WATER QUALITY INDEX
}

\author{
H.S. AL-BAHRANI ${ }^{1,2}$, A.M. AL-DUJAILI ${ }^{3}$, A.S. AL-MOUSAWI ${ }^{3}$ \& H.A. AL-HASNAWI ${ }^{3}$ \\ ${ }^{1}$ Faculty of Engineering, University of Kufa, Iraq \\ ${ }^{2}$ Remote Sensing Center, University of Kufa, Iraq \\ ${ }^{3}$ Faculty of Education for Girls, University of Kufa, Iraq
}

\begin{abstract}
This research aims to study the variation in water quality during four seasons of year 2012-2013 for Husseiniya stream. This stream is a branch of Euphrates river in Iraq. It passes through Karbala Governorate and serves as a source for different purposes in this region. Canadian Water Quality Index (CWQI) method was used to for the classification of this stream for domestic, irrigation, and aquatic uses during winter, spring, summer, and autumn seasons. This method is classified as relative subindex technique that depends on water quality standards; therefore, water quality parameters were adopted in this method, which were taken from different international standards. These parameters were temperature, turbidity, total dissolved solids, hydrogen power, total hardness, sulphates, chlorides, lead, cadmium, aluminium, and coliform bacteria. In CWQI method, the parameters of Husseiniya stream during the four seasons were compared with their optimum (desirable) and maximum (permissible) standards. It was found that there was clear variation in the classification of CWQI between the two ways. From other side, the seasonal behaviour for this stream was not clear during the study period for all parameters and for all uses.
\end{abstract}

Keywords: Canadian Water Quality Index, Euphrates river, Husseiniya stream.

\section{INTRODUCTION}

Pollution is the most important challenge facing water nowadays. Most rivers all over the world become polluted because of industrial development and climatic changes. Because of this challenge, water quality, now and in the future, is classified as unrenewable resource as it is difficult to return to its natural situation after pollution, and its purification is also slower than its deterioration.

Water is a common good and it represents the most important natural and critical resource essential for the life of man and all living beings. Within the overall framework of policies relating to human food and agriculture, water management should be one of the priorities of these policies, given its necessary presence in any diet.

This research aims to combine the water quality parameters of Husseiniya stream (Iraq) to one unitless value by using Canadian Water Quality Index (CWQI) method. It also aims to study the variation of the water quality parameters in this stream during the four seasons and the effect of climate change phenomena on it. The final result of this research will clear indicators for using this stream for different purposes such as agriculture, domestic, aquatic, and industry.

\section{LITERATURE REVIEW}

Hamedi et al. [1] studied the variation of Iran water quality index for urban watercourse southeast Tehran (Iran) during four seasons. They found that the values of water quality parameters changed depending on the characteristics of each season.

Al-Bahrani [2] used Bhargava Water Quality Index method to prove the deterioration of waters in Euphrates river for irrigation, drinking, and industrial uses before the river is entering into Iraqi lands. He proved in his paper that the deterioration reasons of the water quality in Iraq were external. 
Mourhir et al. [3] proposed a new river water quality index using fuzzy logic. The proposed fuzzy index combines quality indicators prescribed thresholds extracted mainly from the Moroccan and the Quebec water legislations. The new index was used to classify water quality in a number of stations along the basins of Bouregreg-Chaouia and Zizi-Rhéris. The obtained classifications were then compared with the conventional physicochemical water quality index currently in use in Morocco.

Al-Bahrani et al. [4] used remote-sensing technique for spatial predicting and classification of Canadian Water Quality Index of Euphrates river in Iraq for irrigation use. They took 16 stations along the river and built water quality classification model for irrigation use on the satellite image of the river.

Al-Bahrani et al. [5] classified according to Bhargava Water Quality Index method of the Euphrates river in Iraq by using satellite image analyses. They built water quality classification model for irrigation use on the mosaic satellite image of the river inside Iraq.

\section{WATER QUALITY INDEX}

Nikbakht [6] deteremined that water quality indices are tools to determine conditions of water quality and, like any other tool, require knowledge about principles and basic concepts of water and related issues. According to Brown et al. [7], it is a well-known method of expressing water quality that offers a stable and reproducible unit of measure, which responds to changes in the principal characteristics of water. Al Meini [8] suggested that water quality indices aim at giving a single value to the water quality of a source on the basis of one or other system, that is, they translate the list of constituents and their concentrati ons present in a sample into a single value.

WQI is a mechanism for presenting a cumulatively derived numerical expression defining a certain level of water quality. In other words, WQI summarizes large amounts of water quality data into simple terms (e.g. excellent, good, bad, etc.) [9]. The simple definition of WQI may be summarized as a unitless number on a scale from 0 to 100 . The better the water quality, the higher the value of the index. Very clean water has an index of 100 , and very polluted water has an index of 0 [10] .

The CWQI method includes three factors, each of which has been scaled between 0 and 100 . The values of the three measures of variance from selected objectives for water quality are combined to create a vector in an imaginary objective exceedance space. The length of the vector is then scaled to range between 0 and 100, and subtracted from 100 to produce an index which is 0 or close to 0 for poor water quality, and close to 100 for excellent water quality. The revised CWQI consists of the following three factors [4].

\subsection{Factor 1 (F1): scope}

This factor is called scope because it assesses the extent of the non-compliance of water quality guideline over the time period of interest:

$$
F_{1}=\frac{\text { number of failed variables }}{\text { total number of variables }} \times 100
$$

where variables indicate those water quality parameters with objectives which are tested during the time period for the index calculation.

3.2 Factor 2 (F2): frequency

It represents the percentage of individual tests that do not meet the objectives ('failed tests'): 


$$
F_{2}=\frac{\text { number of failed tests }}{\text { total number of tests }} \times 100
$$

\subsection{Factor 3 (F3): amplitude}

It represents the amount by which the failed test values do not meet their objectives, and is calculated in three steps:

(i) The number of times by which an individual concentration is greater (or lesser, when the objective is a minimum) the objective is termed an excursion and is expressed as follows. When the test value must not exceed the objective:

$$
\text { excursion }_{\mathrm{i}}=\left(\frac{\text { failed test value }_{\mathrm{i}}}{\text { Objective }_{\mathrm{j}}}\right)-1
$$

For the cases in which the test value must not fall below the objective:

$$
\text { excursion }_{\mathrm{i}}=\left(\frac{\text { objective }_{\mathrm{j}}}{{\text { failed test } \text { value }_{\mathrm{i}}}_{\mathrm{f}}}\right)-1
$$

(ii) The collective amount by which individual tests are out of compliance is calculated by summing the excursions of individual tests from their objectives and dividing by the total number of tests (those which do and do not meet their objectives). This variable, referred to as the normalized sum of excursions, or nse, is calculated as

$$
\text { nse }=\frac{\sum_{i=1}^{n} \text { excursion }_{\mathrm{i}}}{\text { no. of tests }}
$$

(iii) F3 is then calculated by an asymptotic function that scales the normalized sum of the excursions from objectives (nse) to yield a range between 0 and 100

$$
F_{3}=\left(\frac{\text { nse }}{0.01 \text { nse }+0.01}\right)
$$

The CWQI is finally calculated as

$$
\mathrm{CWQI}=100-\left(\frac{\sqrt{F_{1}^{2}+F_{2}^{2}+F_{3}^{2}}}{1.732}\right)
$$

The factor of 1.732 arises because each of the three individual index factors can range as high as 100 . This means that the vector length can reach $\sqrt{100^{2}+100^{2}+100^{2}}=\sqrt{30,000}=173.2$ as a maximum. Division by 1.732 brings the vector length down to 100 as a maximum.

For each indicator, the grading scale followed the 'ranking' scale recommended by the CCME [11]. That scale also used five categories or levels that corresponded to specific levels of water 
Table 1: Grading scale and rational used for all Water Quality Indicators [11].

\begin{tabular}{|c|c|c|c|}
\hline $\begin{array}{l}\text { Indicator } \\
\text { (100-point scale) }\end{array}$ & Ecological condition & Score & Grade \\
\hline $95-100$ & $\begin{array}{l}\text { Excellent: Water quality is protected with virtual } \\
\text { absence of threat or impairment; conditions } \\
\text { very close natural or pristine levels }\end{array}$ & 4 & A \\
\hline $80-94$ & $\begin{array}{l}\text { Good: Water quality is protected with only minor } \\
\text { degree of threat or impairment; conditions } \\
\text { rarely depart from natural or desirable levels }\end{array}$ & 3 & B \\
\hline $65-79$ & $\begin{array}{l}\text { Fair: Water quality is usually protected but } \\
\text { occasionally threatened or impaired; conditions } \\
\text { sometimes depart from natural or desirable } \\
\text { levels }\end{array}$ & 2 & $\mathrm{C}$ \\
\hline $45-64$ & $\begin{array}{l}\text { Marginal: Water quality is frequently threatened } \\
\text { or impaired; conditions often depart from } \\
\text { natural or desirable levels }\end{array}$ & 1 & $\mathrm{D}$ \\
\hline $0-44$ & $\begin{array}{l}\text { Poor: Water quality is almost always threatened } \\
\text { or impaired; conditions usually depart from } \\
\text { natural or desirable levels }\end{array}$ & 0 & $\mathrm{~F}$ \\
\hline
\end{tabular}

quality impairment (Table 1). The Water Quality Index was calculated as the 'grade point average' of the component indicators and was reported as a Grade (i.e. A-F) and a Score.

\section{HUSSEINIYA WATER QUALITY PARAMETERS}

Husseiniya stream is a branch of Euphrates river, passing through Karbala Governorate in Iraq as shown in Fig. 1. Its waters were used for domestic, irrigation, aquatic, and other different purposes [12]. The average of its discharge is $17.1 \mathrm{~m}^{3} / \mathrm{sec}$.

The climate in this region of Iraq is an arid climate with hot dry summers and cold wet winters. The spring and autumn seasons are relatively short and characterized by moderate temperature [13].

The real duration of solar radiation changed temporally during the four seasons in the case study. It increases to be $11.4 \mathrm{hr} /$ day as an average in July (summer) and decreases to be $7.14 \mathrm{hr} /$ day as an average in February (winter). In autumn and spring, the average real solar radiation is 7.21 and 8.35 $\mathrm{hr} / \mathrm{day}$ in November and March, respectively [14]. The temperature also increases to greater than $45^{\circ} \mathrm{C}$ in summer and decreases to less than $10^{\circ} \mathrm{C}$ in winter.

The hypothesis of this study depends on the variation in solar radiation and in temperature that affect the water quality because the high values of these two factors increase the water evaporation and then increase the concentrations of pollutants in water. Therefore, this study will test the seasonal effect on water quality and it also test if the stream is affected by variation in temperature and solar radiation during the four seasons of the year.

Four samples were taken from the mouth of Husseiniya stream during the four seasons of year 2012-2013. The autumn sample was taken from the stream at 4/11/2012, while the three other samples were taken at 3/2/2013,7/4/2013, and 1/7/2013, respectively. Eleven water quality parameters 


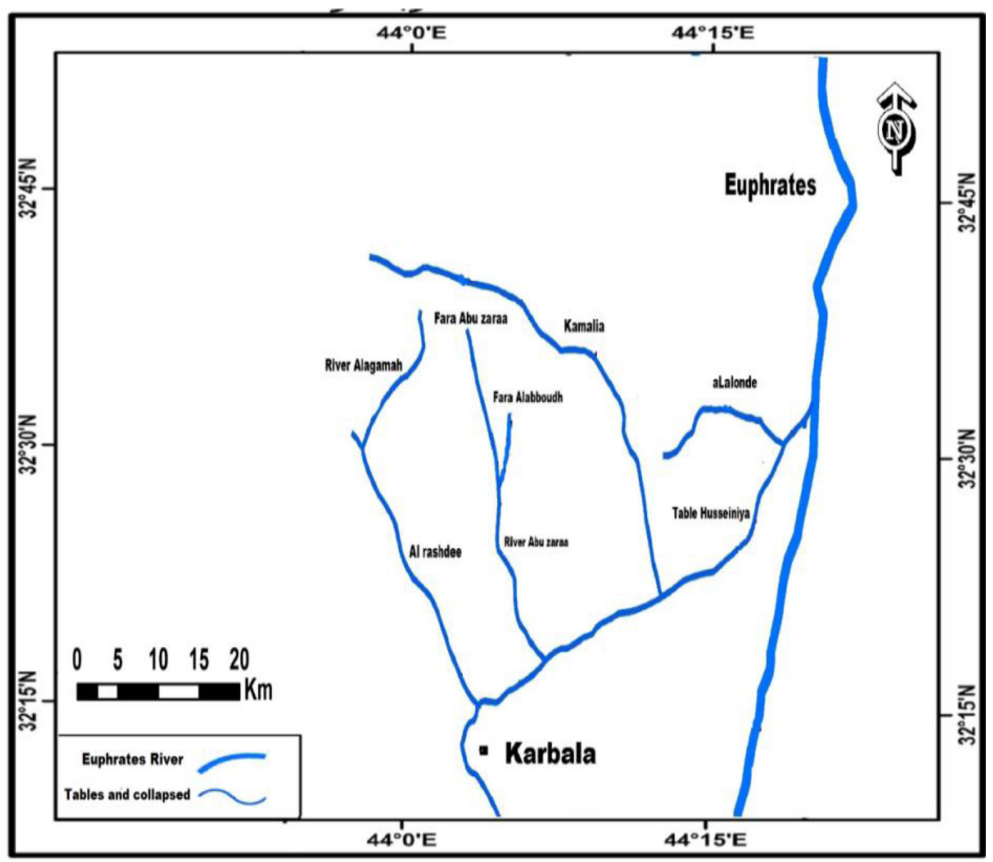

Figure 1: Euphrates river (Husseiniya stream).

were measured from these four samples. These parameters are temperature, turbidity, total dissolved solids (TDS), hydrogen power $(\mathrm{pH})$, total hardness $(\mathrm{TH})$, sulfates ( $\left.\mathrm{SO}^{2}\right)$, chlorides $(\mathrm{Cl})$, lead $(\mathrm{Pb})$, cadmium (Cd), aluminum ( $\mathrm{Al}$ ), and coliform bacteria [14].

Optimum (desirable) and maximum (permissible) standards of these water quality parameters for domestic, irrigation, and aquatic uses are illustrated in Table 2 [15-17]. The values of these water quality parameters during the four seasons of year 2012-2013 are shown in Figs 2 and 3.

It is clear from Figs 2 and 3 that there were no clear differences between the values of water quality parameters during the four seasons. This means that there were no similar changes for all parameters in certain season in spite of that the temperature difference between winter and summer was $20^{\circ} \mathrm{C}$ during the measuring period (2012/2013). It is seen that the values of temperature, turbidity, and lead were greater in summer than other seasons. Aluminum concentration was high in spring than other seasons, while the count of coliform bacteria was more in autumn. It is observed from comparing between the values of water quality parameters in Figs 2 and 3 with optimum and maximum standards in Table 2 that the values of some parameters are located between the two limits. The others were smaller or greater than the two limits for the three uses.

\section{CWQI APPLICATION ON HUSSEINIYA STREAM}

CWQI was calculated for Husseiniya stream during the four seasons of the year 2012-2013. These indices were calculated once for optimum characteristics of water quality standards and the other for maximum characteristics of water quality standards.

CWQIs were calculated for domestic, irrigation, and aquatic uses as shown in Figs 4 and 5. Classifications of these indices were illustrated in Table 3. 
Table 2: Optimum and maximum characteristics of water quality parameters for domestic, irrigation, and aquatic uses [15-17].

\begin{tabular}{|c|c|c|c|c|c|}
\hline Parameters & Unit & Standards & Domestic & Irrigation & Aquatic \\
\hline \multirow{2}{*}{ Temperature } & \multirow{2}{*}{${ }^{\circ} \mathrm{C}$} & Opt. & 15 & NA & 18 \\
\hline & & Max. & 15 & NA & 18 \\
\hline \multirow{2}{*}{ Turbidity } & \multirow{2}{*}{$\mathrm{mg} / \mathrm{l}$} & Opt. & 5 & NA & 5 \\
\hline & & Max. & 20 & NA & 20 \\
\hline \multirow{2}{*}{ TDS } & \multirow{2}{*}{$\mathrm{mg} / \mathrm{l}$} & Opt. & 500 & 500 & 1000 \\
\hline & & Max. & 1500 & 2000 & 50,000 \\
\hline \multirow{2}{*}{$\mathrm{pH}$} & \multirow{2}{*}{ Unitless } & Opt. & $6.8-7.2$ & $6.5-8.5$ & $6.5-8.5$ \\
\hline & & Max. & $6.6-8.0$ & $6.0-9.0$ & $6.5-8.5$ \\
\hline \multirow{2}{*}{$\mathrm{TH}$} & \multirow{2}{*}{$\mathrm{mg} / \mathrm{l}$} & Opt. & 100 & NA & NA \\
\hline & & Max. & 250 & NA & NA \\
\hline \multirow{2}{*}{ Sulfates } & \multirow{2}{*}{$\mathrm{mg} / \mathrm{l}$} & Opt. & 250 & 500 & NA \\
\hline & & Max. & 500 & 1000 & NA \\
\hline \multirow{2}{*}{ Chlorides } & \multirow{2}{*}{$\mathrm{mg} / \mathrm{l}$} & Opt. & 250 & 250 & 1000 \\
\hline & & Max. & 750 & 750 & 2500 \\
\hline \multirow{2}{*}{ Lead } & \multirow{2}{*}{$\mathrm{ppb}$} & Opt. & 0.01 & 0.2 & 0.001 \\
\hline & & Max. & 0.01 & 5 & 0.001 \\
\hline \multirow{2}{*}{ Cadmium } & \multirow{2}{*}{$\mathrm{ppb}$} & Opt. & 5 & 5 & 0.02 \\
\hline & & Max. & 5 & 10 & 0.02 \\
\hline \multirow{2}{*}{ Aluminum } & \multirow{2}{*}{$\mathrm{mg} / \mathrm{l}$} & Opt. & 0.2 & 5 & 0.025 \\
\hline & & Max. & 0.2 & 5 & 0.025 \\
\hline \multirow{2}{*}{$\begin{array}{l}\text { Coliform } \\
\text { bacteria }\end{array}$} & \multirow{2}{*}{$/ 100 \mathrm{ml}$} & Opt. & 100 & 1000 & 1000 \\
\hline & & Max. & 5000 & 10,000 & 10,000 \\
\hline
\end{tabular}

\section{CONCLUSIONS}

It is seen from Fig. 4 and Table 3 that Husseiniya stream was suitable for irrigation of not sensitive crops at those period because it was classified as fair and marginal for optimum characteristics. It is not recommended to use the water of this stream for domestic purposes without primary, secondary, and advance treatments. It is noticed that the water of Husseiniya stream at that time was not optimal for aquatic uses because its classification fluctuated between poor and marginal.

According to Fig. 5 and Table 3, the irrigation water of this stream can be classified as Excellent for winter, spring, and summer seasons. For autumn season its quality for irrigation was reduced to classify as Good.

There were no similar differences for all values of water quality parameters in certain season of the study period. This means that there are no effects for seasonal changes on the water quality of the Husseiniya stream during the study period. 


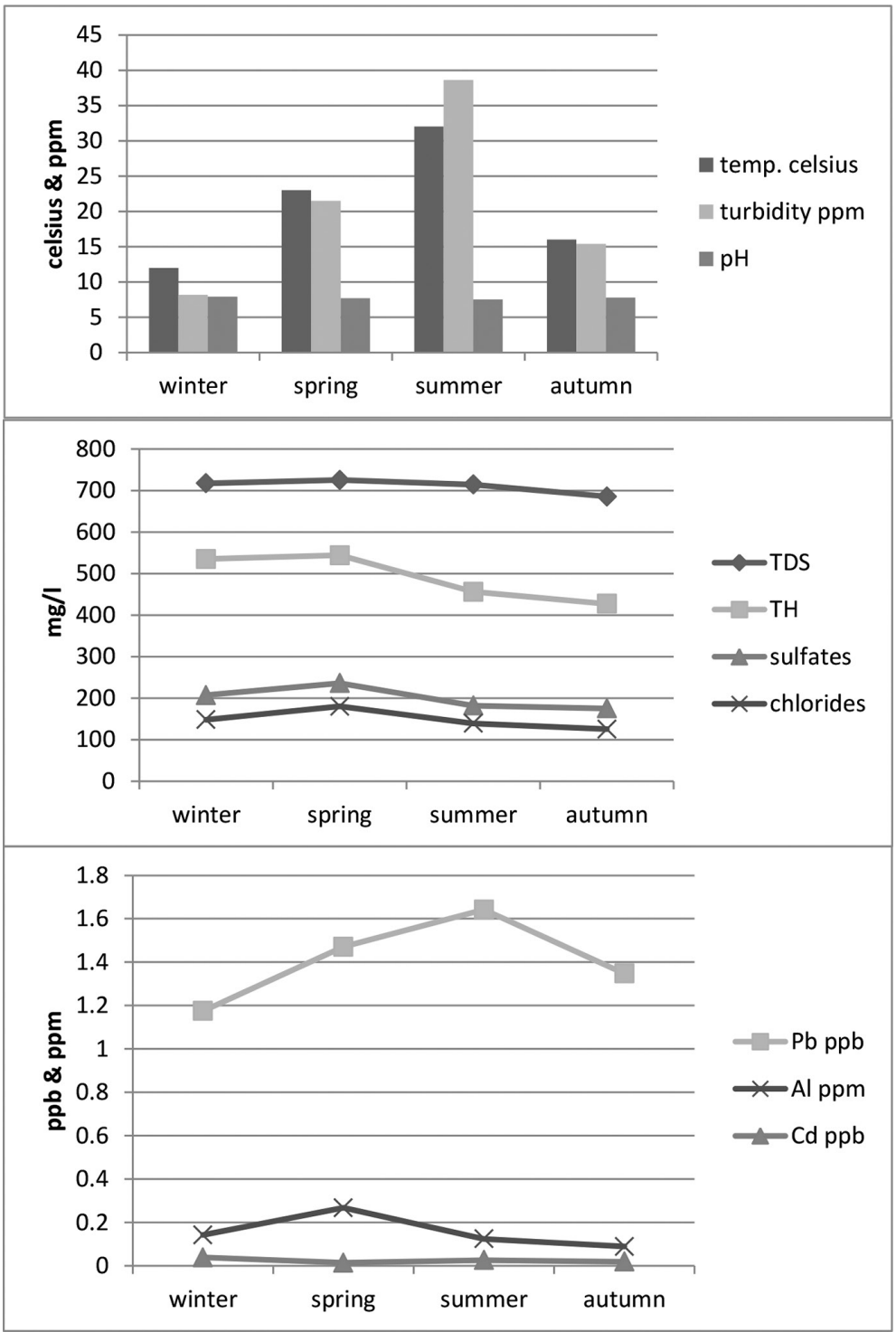

Figure 2: Water quality parameters of Husseiniya stream during year 2012/2013. 


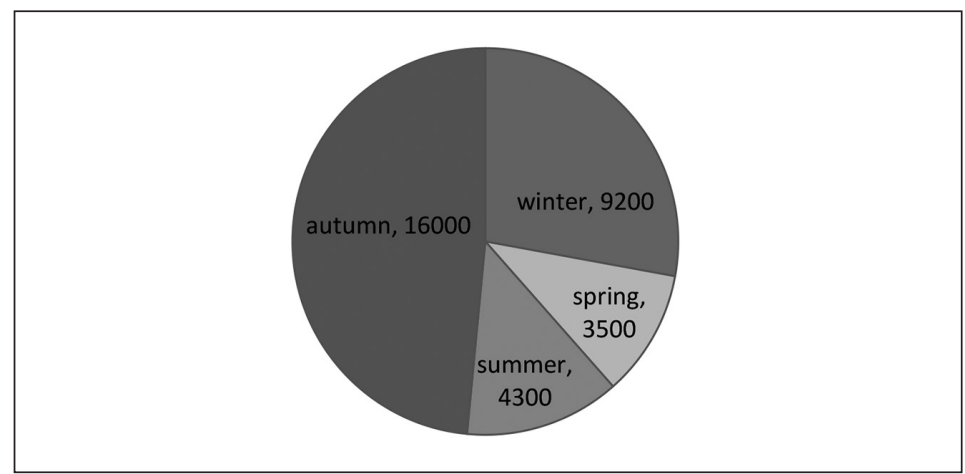

Figure 3: Coliform bacteria (no./100 ml) for Husseiniya stream during year 2012/2013.

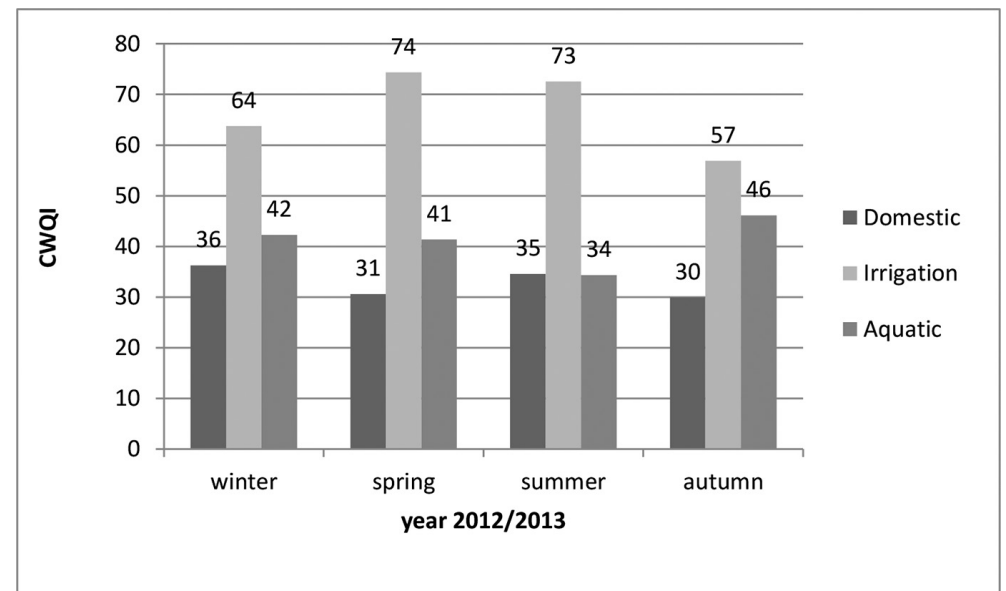

Figure 4: Water quality index for Husseiniya stream according to Canadian method comparing the optimum characteristics.

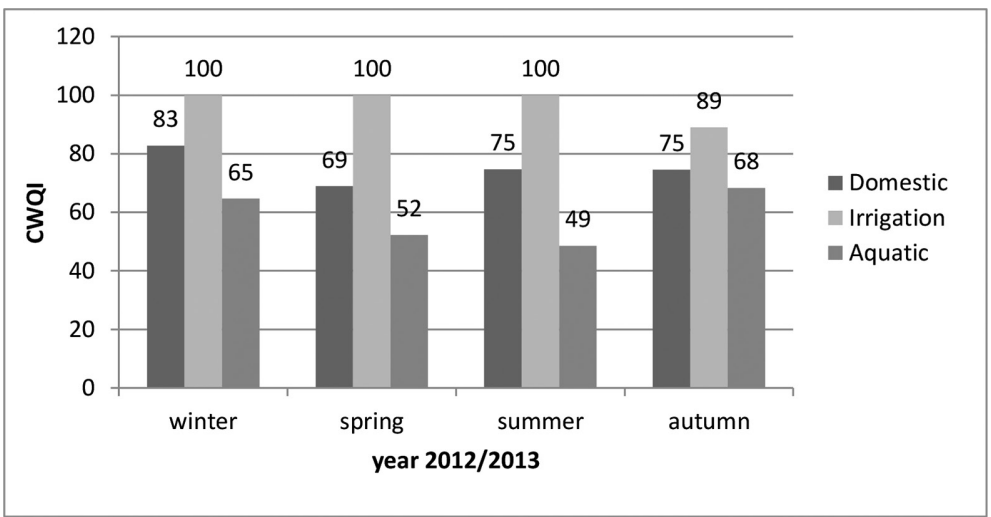

Figure 5: Water quality index for Husseiniya stream according to Canadian method comparing the maximum characteristics. 
Table 3: Water quality classifications of Husseiniya stream according to Canadian water quality index during year 2012-2013.

\begin{tabular}{lllllll}
\hline & \multicolumn{3}{c}{ Domestic use } & \multicolumn{2}{c}{ Irrigation use } & \multicolumn{2}{c}{ Aquatic use } \\
\cline { 2 - 7 } Season & Opt. & Max. & Opt. & Max. & Opt. & Max. \\
\hline Winter & Poor & Good & Marginal & Excellent & Poor & Marginal \\
Spring & Poor & Fair & Fair & Excellent & Poor & Marginal \\
Summer & Poor & Fair & Fair & Excellent & Poor & Marginal \\
Autumn & Poor & Fair & Marginal & Good & Marginal & Fair \\
\hline
\end{tabular}

\section{REFERENCES}

[1] Hamedi, H., Mobarghai, N, Soufizadeh, S. \& Rasouli, S.A., Survey of qualitative conditions and seasonal variation of the urban watercourses pollutants. J. Mater. Environ. Sci., 6(2), pp. 322-332, 2015.

[2] Al-Bahrani, H.S., Water quality deterioration of the Euphrates River before entering Iraqi lands. WIT Transactions on Ecology and the Environment, 182, pp. 3-14, 2014, ISSN 1743-3541 (on-line), doi: 10.2495/WP140011

[3] Mourhir, A., Ralitachidi, T. \& Karim, M., River water quality index for Morocco fuzzy inference system. Environmental System Research, 3, p. 21, doi: 2014, doi: 10.1186/s40068014-0021-y

[4] Al-Bahrani, H.S., Abdulrazzaq, K.A. \& Saleh, S.A., Remote sensing for the irrigation water quality index of Euphrates River according to the Canadian method, Kufa Journal for Agriculture Sciences (3rd Scientific Conference for Agriculture College), Faculty of Agriculture, University of Kufa, Iraq, No. 5, pp. 49-69, 2013.

[5] Al-Bahrani, H.S., Abdul Razzaq, K.A. \& Saleh, S.A., Remote sensing of water quality index for irrigation usability of Euphrates River. WIT Transactions on Ecology and the Environment, 164, pp. 55-66, 2012, ISSN 1743-3541 (on-line), doi: 10.2495/WP 120051

[6] Nikbakht, M., The effect assessment of Ahvaz No.1, 2 water treatment plant on Karoon water quality, M.Sc Thesis, Ahvaz IA University, 2004.

[7] Brown, R.M., McLelland, N.I., Deininger, R.A. \& O’Connor, M.F., A water quality index - crashing the psychological barrier. Indicators of Environmental Quality, 1972. doi: http:// dx.doi.org/10.1007/978-1-4684-1698-5_15

[8] Al Meini, A.J.K., A proposed index of water quality assessment for irrigation. Eng. \& Tech. Journal, 28(22), pp. 1-18, 2010

[9] Bordalo, A.A., Teixeira, R. \& Wiebe, W.J., A water quality index applied to an international shared river basin: the case of the Douro River. Environmental, 38, pp. 910-920, 2006. doi: http://dx.doi.org/10.1007/s00267-004-0037-6

[10] Dojlido, J., Raniszewski, J. \& Woysie, C.J., Water quality applied to rivers in the Vistula river basin in Poland. Environmental Monitoring and Assessment, 33, pp. 33-42, 1994. doi: http:// dx.doi.org/10.1007/bf00546659

[11] CCME, 'Canadian water quality guidelines for the protection of aquatic life', Canadian Council of Ministers of the environment, Manitoba Statuary Publications, Winnipeg, Canada, 2001. 
[12] Al-Msuoodi, R.M., The water resources and their role on the agricultural production in Karbalaa Governorate, M.Sc. thesis, College of Science, University of Tikrit, Iraq, 2000.

[13] Al-Asady, H.K., Evaluation of irrigation network of Husseiniya Irrigation Project using geomatics techniques, M.Sc. Message, University of Technology, Iraq, 2014.

[14] Al-Hasnawi, H.A., An ecological study of the characteristic of drinking water in the city of Karbala, M.Sc., Faculty of Education for Girls, University of Kufa, Iraq, 2013.

[15] Zegel, W.C, Environmental Engineering Handbook Standards, CRC Press: Boca Raton, FL, 1999.

[16] FAO, Water quality for agriculture, Corporate Document Repository, FAO Irrigation and Drainage Papers, Job No.: T0234, Version: 29, ISSN: 0254-5284, Rome, Italy, 1994. http:// www.fao.org/DOCREP/003/T0234E/T0234E00.HTM

[17] Warrnigton, P.D., Water quality criteria for microbiological indicators, Overview report, second edition, Environmental Protection Division, Ministry of Water, Land and Air Protection, Government of British Colombia, 2001. 